\title{
АВТОМАТИЗОВАНИЙ ЗАСІБ ПІДВИЩЕННЯ БЕЗПЕКИ ПІД ЧАС ПЕРЕВАНТАЖЕННЯ ЗЕРНОВИХ КУЛЬТУР НА СУДНАХ
}

\author{
Сандлер А. К. ${ }^{1}$, Опришко М. О. ${ }^{2}$ \\ ${ }^{1,2}$ Національний університет "Одеська морська академія", м. Одеса, Україна \\ E-mail: ${ }^{1}$ albertsand4@gmail.com
}

Copyright (C) 2021 by author and the journal “Automation of technological and business - processes”. This work is licensed under the Creative Commons Attribution International License (CC BY). http://creativecommons.org/licanses/by/4.0
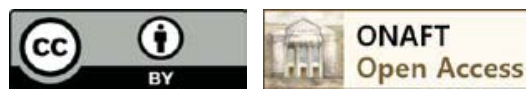

DOI:

Анотація. Правила ІМО по перевезенню зерна вимагають дотримання мінімального рівня прийнятної остійності для перевезення зерна, визначеного кутом крену внаслідок умовного зсуву зерна, залишкової відновлювальної енергії, після такого передбачуваного зсуву зерна, й початкової метацентричної висоти. Сучасні навантажувальні комплекси для перевалки зернових культур мають високу продуктивність, щяо зобов'язує здійснювати постійний контроль положення судна, у тому числі вносити корективи в довжину й натяг швартовних канатів. Поряд зі швартовними лебідками, брашпилями й шпилями в ияьому процесі беруть участь і динамічні швартовні кнехти. Аналіз швартовних обладнань показав, щчо найбільш ефективним для корекиії положення судна є застосування керованих кнехтів у комплексі з автоматичним лебідками. Однак, досвід застосування керованих кнехтів відомих конструкцій, свідчить, щзо в їхніх конструкціях закладені рішення, щз у значній мірі обмежують можливості використання при положенні судна, яке швидко змінюється, чи в складних кліматичних умовах. Пропонована конструкиія відрізняється тим, щзо тумби мають електромеханічні стопори з датчиками зусилля, пальці встановлені на осях обертання тумб $i$ з'єднані з валами п'єзоелектричних двигунів, які жорстко приєднані до основи, і разом зі стопором з'єднані із блоком керування. Таким чином, розроблене обладнання забезпечить: розширення діапазону експлуатаційних режимів застосування швартовних кнехтів завдяки застосуванню п'єзоелектричних двигунів; спрощення конструктивного виконання; відсутність необхідності компенсації впливу кліматичних факторів на елементи кнехта; відсутність загрози забруднення навколишнього середовища вуглеводневими робочими речовинами; підвищення ремонтопридатності за рахунок обрання модульної конструкції. Використання розробленого обладнання дозволить оперативно підтримувати безпеку положенням судна при вантажних операџіях

Abstract. IMO Grain Regulations require a minimum level of acceptable stability for grain transportation, represented by the roll angle due to the conditional grain displacement, the residual restoring energy after such an assumed grain displacement and the initial metacentric height. Modern loading complexes for transshipment of grain crops are highly productive, which requires constant monitoring of the ship's position, including adjusting the length and tension of the mooring ropes. Along with mooring winches, windlass and capstan, dynamic mooring cleats are also involved in this process. The analysis of the mooring devices showed that the most effective for correcting the position of the vessel is the use of controlled bollards in combination with automatic winches. However, the experience of using the controlled bollards of known designs indicates that their designs contain solutions that significantly limit the possibilities of use in the rapidly changing position of the vessel or in difficult climatic conditions. The proposed design differs in that the pedestals have electromechanical stoppers with force sensors, the fingers are installed on the axes of rotation of the pedestals and are connected to the shafts of piezoelectric motors, which are rigidly attached to the base, and together with the stopper are connected to the control unit. Thus, the developed device will provide: expansion of the range of operating modes for the use of mooring bollards due to the use of piezoelectric motors; simplification of the design; no need to compensate for the influence of climatic factors on the bollard elements; no threat of environmental pollution by hydrocarbon working substances; improving maintainability due to the choice of a modular design. The use of the developed device will make it possible to quickly maintain a safe position of the ship during cargo operations. Thus, the developed device will provide: - expansion of the range of operating modes for the use of mooring bollards due to the use of piezoelectric motors; - simplification of design implementation; - no need to compensate for the influence of climatic factors on the bollard elements; - no threat of environmental pollution by hydrocarbon working substances; - increase in maintainability due to the choice of modular design 
and availability for technical diagnostics. The use of the developed device will allow to promptly maintain safety by the position of the vessel during cargo operations.

Ключові слова: зерно, судно, кнехт, швартування

Keywords: grain, ship, bollard, mooring

\section{Вступ}

Зерно перевозиться на судах не одну тисячу років. Це питання привертає до себе увагу і є одним 3 головних на морському ринку в силу своєї важливості й особливих проблем, що виникають у цьому зв'язку. Тенденція зерна, яке транспортується насипом у натуральному вигляді, пересипатися в межах вантажного простору судна, що випробовує хитавицю, становить потенційну небезпеку для судна й команди. Тому проблеми, що виникають у зв'язку з таким перевезенням, часто стають предметом національних вимог і міжнародних угод.

Міжнародні правила, застосовувані під час перевезення зерна насипом, об'єднані в главі VI Конвенції СОЛАС1974 - "Перевезення вантажів". Ці правила показали свою ефективність відносно безпеки. Правила International Maritime Organization (IMO) по перевезенню зерна засновані на визнанні того, що у відсіку, заповненому зерном, існує порожній простір між поверхнею зерна й палубою завантаженого відсіку. Правила вимагають доказу розрахунками того, що протягом усього рейсу судно в неушкодженому стані буде мати достатню остійність, що забезпечує адекватну залишкову динамічну остійність із урахуванням моментів, що створюють крен, за схемою умовного зсуву зерна в порожнечах, що перебувають безпосередньо над поверхнями зерна. Установка тимчасових обладнань для перевезення зерна, що забезпечують зниження впливів від зсуву зерна, наприклад шифтингбордсів, повністю залежить від правильного співвідношення між характеристиками остійності судна в неушкодженому стані, що моментами, що створюють крен, від можливого зсуву зерна в межах різних відсіків судна. Правила IMO по перевезенню зерна вимагають дотримання мінімального рівня прийнятної остійності для перевезення зерна, представленого кутом крену внаслідок умовного зсуву зерна, залишкової енергії, що відновлює, після такого передбачуваного зсуву зерна й початкової метацентричної висоти [1].

Сучасні навантажувальні комплекси для перевалки зернових культур мають високу продуктивність, що зобов'язує робити постійний контроль положення судна, у тому числі вносити корективи в довжину й натяг швартовних канатів. Поряд зі швартовними лебідками, брашпилями й шпилями в цьому процесі беруть участь і динамічні швартовні кнехти [2].

\section{Аналіз літературних джерел і постановка завдання}

Аналіз швартовних обладнань показав, що найбільш ефективним для корекції положення судна є застосування керованих кнехтом у комплексі з автоматичним лебідками. Однак, досвід застосування керованих кнехтів відомих конструкцій, свідчить, що в їхніх конструкціях закладені рішення, у значній мірі обмежуючі можливості використання при положенні судна, яке швидко змінюються, чи в складних кліматичних умовах.

Для пошуку шляхів поліпшення характеристик динамічних швартовних кнехтів були розглянуті схемотехнічні рішення обладнань відомих типів.

Найпоширеніша конструкція кнехта, що складається з основи й тумб із підшипниками (рис. 1)[3].

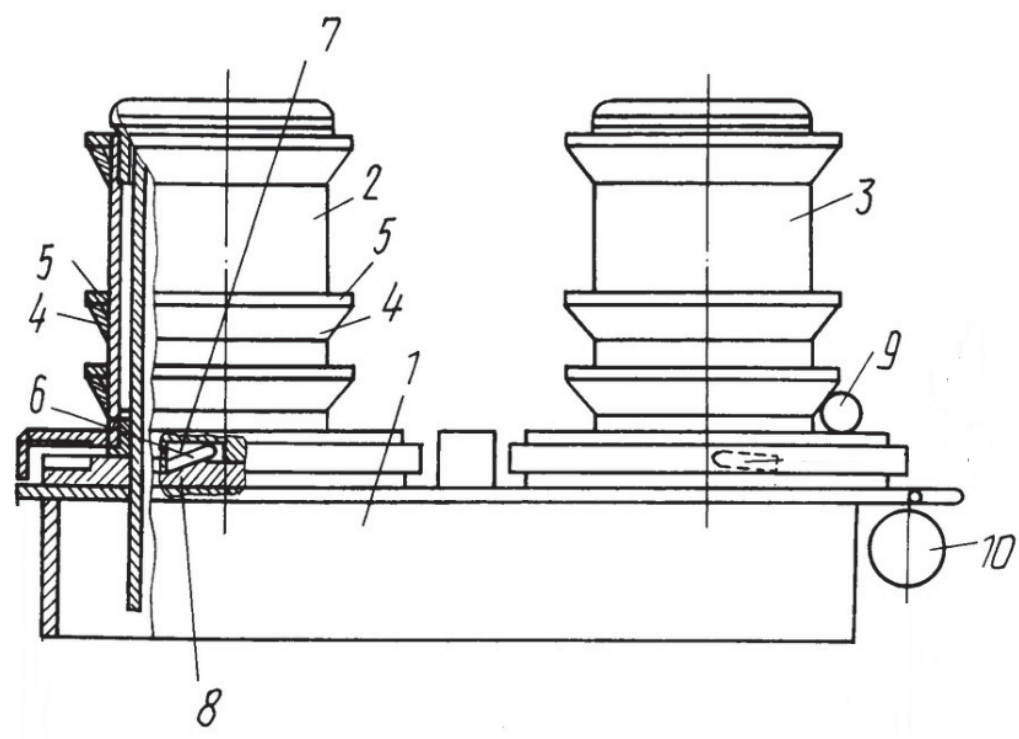

Рис. 1. - Кнехт із обертовими тумбами: 1 - основа; 1, 3 - обертові тумби; 4 - конічне кільце; 5 - пласке кільце; 6 - стопорний елемент-собачка; 7 - паз; 8 - храповик. 
До основних недоліків обладнання, обумовленим використанням тумб, що вільно обертаються у підшипниках, можна віднести:

- вузький діапазон робочих режимів;

- відсутність можливості керування натягом швартовних канатів, які закріплені на кнехті, без допомоги брашпиля або шпиля.

Більш досконалим є конструкція швартовного кнехта з гідроприводом (рис. 2) [4].

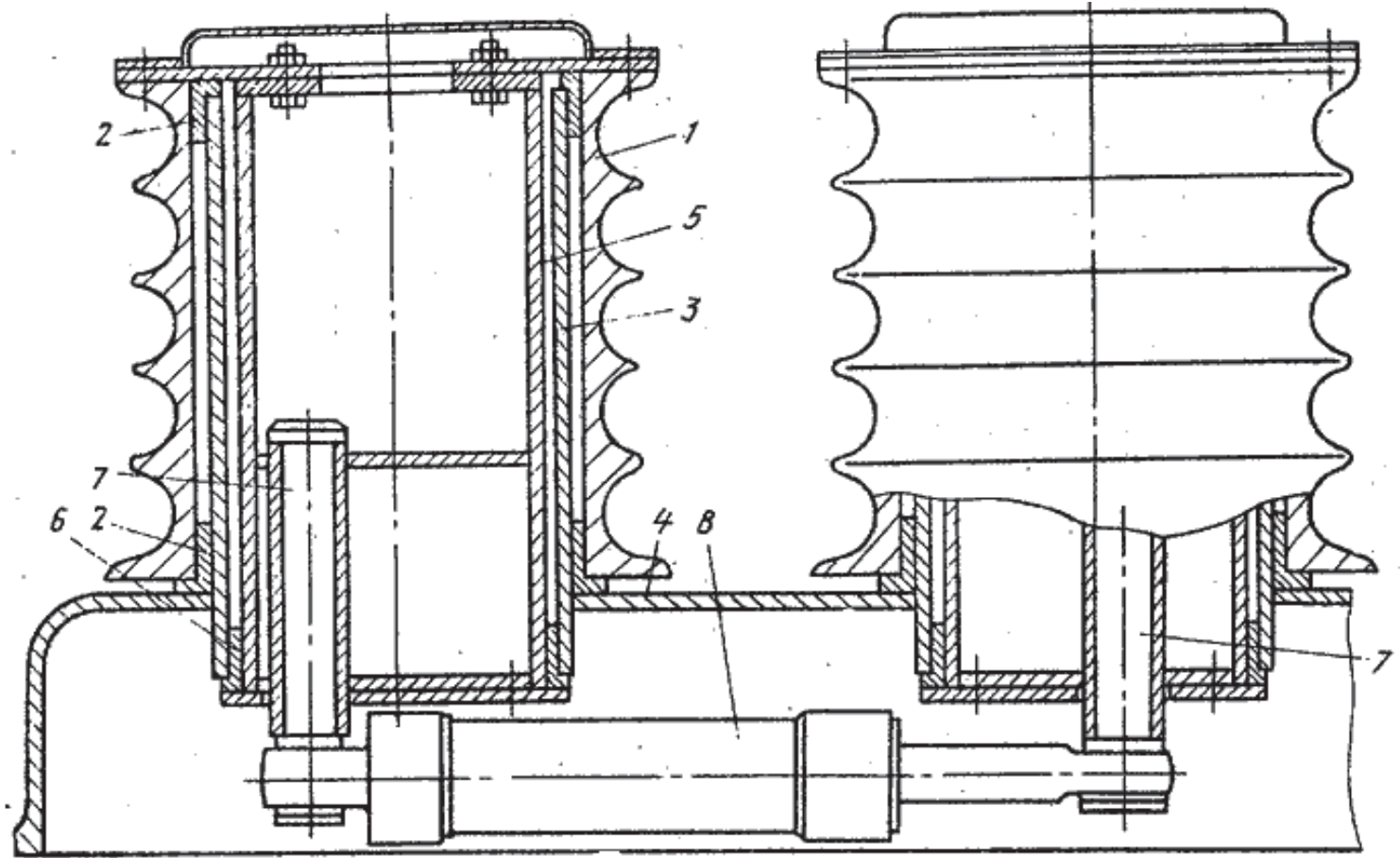

Рис. 2. - Кнехт із гідроприводом: 1 - тумби; 2 - підшипники; 3 - цапфи; 4 - опора; 5 - труба; 6 -опора-підшипник; 7 - пальці; 8 - гідроциліндр.

Обладнання має розширений діапазон робочих режимів. Однак зазначеної конструкції властиві ряд недоліків, обумовлених використанням гідравлічної системи:

- загроза забруднення навколишнього середовища вуглеводневими робочими речовинами;

- необхідність компенсації впливу кліматичних факторів на властивості робочої речовини кнехта;

- необхідність додаткової насосної станції.

\section{Ціль і завдання дослідження}

Проведений аналіз дозволив конкретизувати вимоги до нового конструктиву динамічного кнехта. Для усунення недоліків, властивих [3, 4] у розроблювальному обладнанні повинні бути присутні:

- розширений діапазон робочих режимів;

- підвищена захищеність елементів від неконтрольованих експлуатаційних факторів;

- відсутня загроза забруднення навколишнього середовища вуглеводневими робочими речовинами;

- збережені ефективні конструктивні рішення кнехтів відомих типів.

\section{Результати досліджень}

У відповідності до вищевикладених вимог розроблений модернізований динамічний кнехт.

Обладнання кнехта наведене на рис. 3, де зображені герметична опорна основа 1, на якій закріплені цапфи 3 підшипником 3, у яких обертаються тумби 2. На опорній основі також закріплений електромеханічний стопор 3 датчиком зусилля 4, робочі поверхні якого взаємодіють із внутрішніми поверхнями тумб. На тумбах закріплені пальці 5, що з'єднуються з валами п'єзоелектричних двигунів 6. Блок керування 7 електрично сполучений з датчиком зусилля й п'єзоелектричними двигунами. П'єзоелектричні двигуни можуть застосовуватися як у режимі додаткового приводу, так і в режимі гальма й демпфера. П'єзоелектричні двигуни можуть застосовуватися спільно або роздільно, з різною частотою обертання й у режимі покрокового обертання.

У статичному режимі (перед початком швартовних операцій), блок керування генерує сигнал на розблокування електромеханічного стопора й провертання п'єзоелектричними двигунами (кілько обертів) тумб кнехта [5](.

У цьому режимі фіксуються відповідні виправлення, які враховують технічний стан елементів кнехта.

У першому динамічному режимі (режим швартування) на кнехт "вісімками" накладають швартовний канат, один кінець якого закріплюється на причальній тумбі. Другий кінець канату закріплюється на турачці брашпиля або голівці шпиля. 


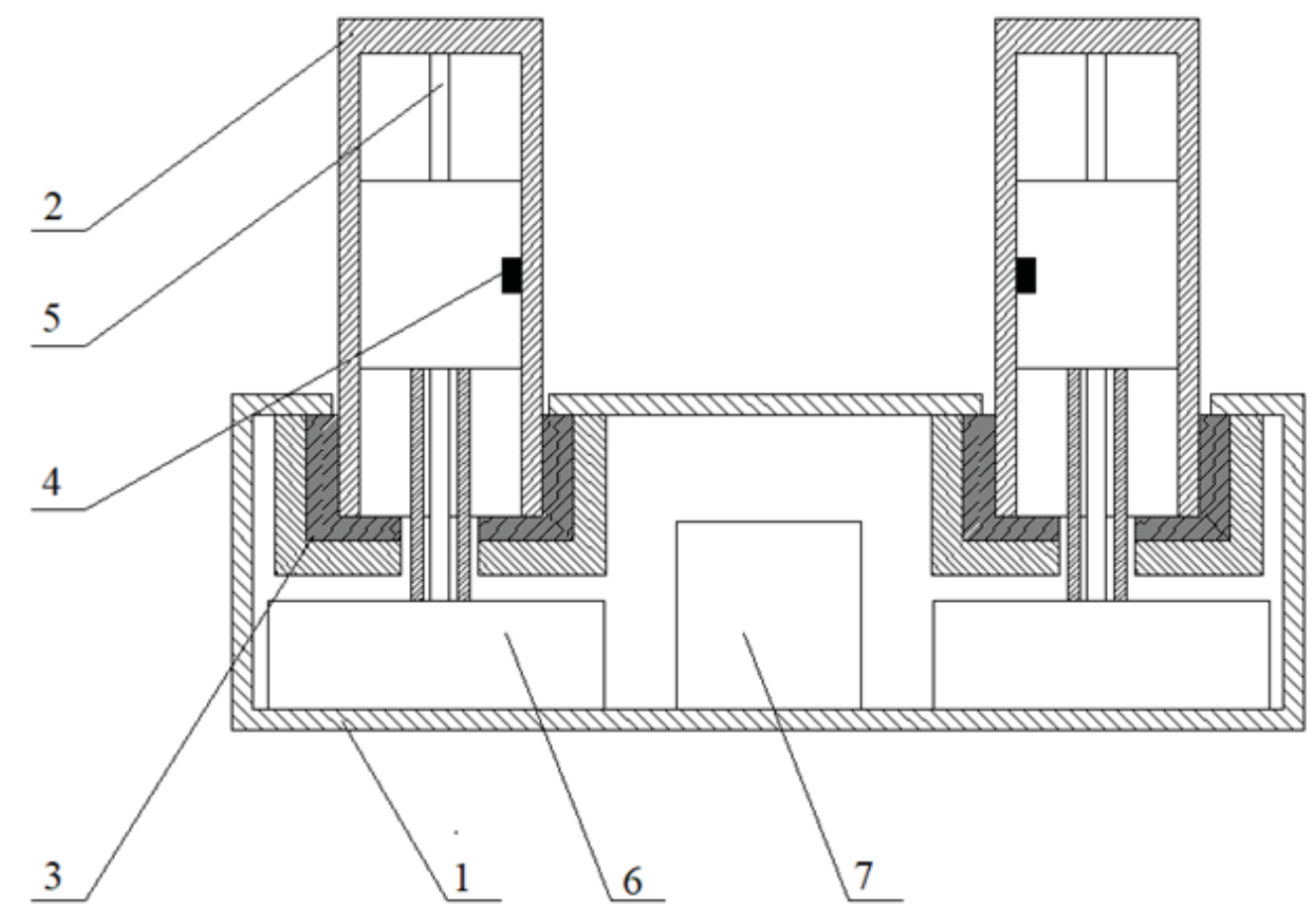

Рис. 3. - Кнехт швартовний: 1 - опорна основа; 2 - тумба; 3 - цапфа 3 підшипником; 4 - електромеханічний стопор 3 датчиком зусилля; 5 - палець; 6 - п'сзоелектричний двигун; 7 - блок керування.

При необхідності протягання канату через кнехт, блок керування задає обертання тумб у протилежних напрямках 3 необхідною швидкістю з попереднім розблокуванням стопора.

Для стопоріння кнехта, після вибірки канату, блок керування включає електромеханічний стопор, який виключає можливість обертання тумб.

У другому динамічному режимі (режим перешвартування при зміні осади при вантажних операціях) від датчика зусилля до блоку керування надходить відповідний сигнал, викликаний зміною натягу швартовних канатів при зміні опади при вантажних операціях. На основі цього сигналу, блок керування розблокує стопор і вводить у дію п'єзоелектричні двигуни. Останні здійснюють покрокове обертання тумб і зміну довжини швартовного канату між кнехтом і причальною тумбою до того моменту, доки датчик зусилля не зафіксує необхідний натяг канату. Це підвищує надійність роботи швартовного обладнання й дозволяє використовувати швартовні канати 3 меншим коефіцієнтом запасу міцності.

У третьому динамічному режимі (режим перемотування швартовних канатів) на одну тумбу кнехта накладається швартовний канат у вигляді петлі, розблокується стопор і вводиться в дію відповідний п'єзоелектричний двигун.

Пропонована конструкція відрізняється тим, що тумби мають електромеханічні стопори 3 датчиками зусилля, пальці встановлені на осях обертання тумб і з'єднані з валами п'єзоелектричних двигунів, які жорстко приєднані до основи, і разом зі стопором з'єднані із блоком керування.

\section{Висновки}

Таким чином, розроблене обладнання забезпечить:

- розширення діапазону експлуатаційних режимів застосування швартовних кнехтів завдяки застосуванню п'єзоелектричних двигунів;

- спрощення конструктивного виконання;

- відсутність необхідності компенсації впливу кліматичних факторів на елементи кнехта;

- відсутність загрози забруднення навколишнього середовища вуглеводневими робочими речовинами;

- підвищення ремонтопридатності за рахунок обрання модульної конструкції й доступність для технічного діагностування [6].

Використання розробленого обладнання дозволить оперативно підтримувати безпечне положенням судна при вантажних операціях [7].

\section{Список використаних джерел}

[1] Международный кодекс по безопасной перевозке зерна насыпью (Принят Резолюцией КБМ от $23.05 .1991 \mathrm{~N}$ MSC.23(59)).

[2] Корнилов, Э.В., Бойко, П.В., Корнилов, В.Э. Палубные механизмы и судовые устройства морских судов. Одесса: Феникс, 2009. - 420 с. 
[3] Gaythwaite J. W. Design of marine facilities for the berthing, mooring and repair of vessels. Van Nostrand Reinhold, New York, 1990, 525 p.

[4] A.c. SU 1065286 А СССР, МКИ3 В 63 В 21/06. Швартовный кнехт / Б. И. Сорокин (СССР). - № 3351499/27-1; заявлено 04.09.81; опубл. 07.01.84, Бюл. № 1 (72). - 3 с.

[5] Лавриненко, В. В., Карташев, И. А., Вишневский, В. С. Пьезоэлектрические двигатели. - М.: Энергия, 1980. $112 \mathrm{c}$.

[6] Веретеннік, О. М., Сандлер, А. К. Технічне діагностування об єктів суднових енергетичних установок: довідник. - Одеса: Фенікс, 2019. - 167 с.

[7] Патент України № 146481. МПК В63В 21/06 (2006.01). Кнехт швартовний / А. К. Сандлер, М. О. Опришко; Заявник та володар патенту Національний університет "Одеська морська академія". - u202006027. - заявл. 21.09.2020; опубл. 25.02.2021, бюл. № 8/2021. - 3 с.

\section{References}

[1] International Code for the Safe Carriage of Grain in Bulk (International Grain Code) MSC.23(59)) [in Ukraine].

[2] Kornilov, E.V., Boyko, P.V., Kornilov, V.E. (2013). Palubnyye mekhanizmy i sudovyye ustroystva morskikh sudov. [Deck mechanisms and ship devices of marine vessels]. Odessa: Phoenix [in Ukraine].

[3] Gaythwaite J. W. Design of marine facilities for the berthing, mooring and repair of vessels. Van Nostrand Reinhold, New York, 1990, 525 p.

[4] Patent SU 1065286 A. (1984). Knekht shvartovyy. [Mooring bollard ]. Sorokin B. I.

[5] Lavrinenko, V. V., Kartashev, I. A., Vishnevskiy, V. S. (1980). P'yezoelektricheskiye dvigateli. [Piezoelectric motors]. Moscow: Energiya [in Russian].

[6] Veretennik, O. M, Sandler, A. K. (2019). Tekhnichne diahnostuvannya ob'yektiv sudnovykh enerhetychnykh ustanovok [Technical diagnostics of objects of ship power installations]. Odessa: Phoenix [in Ukraine].

[7] Patent 146481. Ukraine, IPC. (2021). Knekht shvartovyy. [Mooring bollard] / Applicant and patent holder: Sandler, A. K., Opryshko M. O. № u202006027; 21.09.2020; publ. 25.02.2021; bul. № 8/2021.

Отримана в редакції 02.02.2021. Прийнята до друку 25.02.2021. Received 02 February 2021. Approved 25 February

2021. Available in Internet 31 March 2021.

\section{УДК 004.896:681.586.7:537.226.4}

\section{ЗАСІБ АВТОМАТИЗАЦІї КОНТРОЛЮ ПАРАМЕТРІВ ЕЛЕКТРОЕНЕРГЕТИЧНИХ СИСТЕМ}

\section{Карпилов А. Ю.}

Національний університет "Одеська морська академія", м. Одеса, Україна

E-mail: kau.onma@gmail.com

Copyright (C) 2021 by author and the journal “Automation of technological and business - processes”.

This work is licensed under the Creative Commons Attribution International License (CC BY).

http://creativecommons.org/licanses/by/4.0

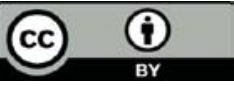

ONAFT

Open Access

DOI:

Анотація. Сучасні технології розвитку суднових енергетичних установок характеризуються, насамперед, показниками ресурсоефективного енергоспоживання. Актуальність удосконалювання цих показників обумовлює появу нових автоматизованих прецизійних способів $і$ засобів контролю основних характеристик електричних пристроїв систем та установок різного призначення. Величина електричного струму, щчо протікає через струмопровідні елементи пристрою, с однісї із ичих характеристик.

У теж час, аналіз існуючих пристроїв контролю електроенергетичних величин показав наступне. Можливості більшості використовуваних датчиків не дозволяють реалізувати ефективний моніторинг електроенергетичних систем. Загальними проблемами для всіх типів засобів контролю електромагнітних параметрів є проблеми чутливості, швидкодії й стабільності чутливого елемента, які визначають вірогідність результатів вимірів. 